\title{
Development of DNA Barcodes for Major Insect Pest of Cole Crops in Mid-Hills of Meghalaya
}

\author{
R. Lalrinfeli ${ }^{*}$, G.T. Behere ${ }^{2}$, D. M. Firake $^{2}$, Bhagawati Sharma ${ }^{2}$, \\ Amrita Banerjee ${ }^{2}$ and T. Rajesh ${ }^{1}$ \\ ${ }^{1}$ College of Post Graduate Studies (CAU), Umroi Road, Umiam, India \\ ${ }^{2}$ ICAR Research Complex for NEH, Region, Umroi Road, Umiam, Meghalaya, India \\ *Corresponding author
}

\begin{tabular}{|l|}
\hline Key w or d s \\
COI, DNA \\
barcoding, \\
Ecosystem, \\
Lepidopteran \\
insects and mtDNA
\end{tabular}

\section{A B S T R A C T}

Significant morphological similarities within or in between species of insects has made reliable taxonomic identification difficult. DNA barcoding has appeared to be a useful tool in resolving the issues related to the identification of taxonomically difficult insect species. The Northeastern region of India is one of the mega biodiversity hotspots in the World and the climatic conditions of the region are highly conducive for reproduction and multiplication of insects. The efforts were undertaken to study the biodiversity of insects and to develop molecular database by developing DNA barcodes of major insect pests of cole crops in mid hills of Meghalaya. Limited information is available on insect pests in cole crops ecosystem in mid -hills of Meghalaya. A total of 12 insect pests belonging to four insect orders viz., Lepidoptera (6), Coleoptera (2), Diptera (2), Hemiptera (2) were documented during the year 2014-2015. The insect species viz., P. brassicae, Spodopteralitura, Myzus persicae and Plutella xylostella were found to be a major pest in this region. The collected species were identified by established taxonomic keys, by taxonomists and/or molecular basis. DNA was successfully extracted from multiple specimens of 12 insect species and molecular assays were also undertaken for presence of Wolbachia infection. The Wolbachia infected specimens were discarded and not used for further analysis. The DNA barcodes were successfully developed for 12 species by sequencing partial Cytochrome oxidase I (COI) gene of mitochondrial DNA. The molecular identity of the insect species was established through BLAST-n at NCBI. The total nucleotide length of barcodes varied from species to species (572bp to 677bp). All the analysed sequences were submitted to National Centre for Biotechnology Information (NCBI) and Accession numbers were obtained (KT175576 to KT175605). The comprehensive taxonomical and molecular database developed in this study for a total of 12 species observed in cole crop ecosystem could be used as diagnostic guide at both morphological and molecular level.

\section{Introduction}

Cole crops, the most abundantly consumed vegetables in the world belonging to the family Brassicaceae comprises about 380 genera and over 3000 species of cultivated and wild plants that have almost similar insect pest complex (Heywood, 1993). Throughout 
the world, a total of 51 insect pests species (Maison, 1965) and a total of 37 insect pest species from India have been reported to feed on cruciferous crops (Lal, 1975). The enormous yield and economic losses in Brassica crop production every year caused by insects is a threat to global agriculture. Sometimes the yield loss by insects reaches as high as $60-70 \%$ and a report has been made that Indian agriculture is currently suffering an annual loss of about ₹ 86.39 million due to insect pests (Dhaliwal et al., 2007). On an average $25-30 \%$ yield loss in vegetables worldwide is caused by insect pests (Reddy and Zehr, 2004).

Significant morphological similarities within or in between species of insects had made reliable taxonomic identification difficult. DNA barcoding has appeared to be a useful tool in resolving the issues related to the identification of taxonomically difficult insect species. The efforts were undertaken to study the biodiversity of insects and to develop molecular database by developing DNA barcodes of major insect pests of cole crops in mid hills of Meghalaya.

North east India, considered as one of the mega biodiversity hot spots has a predominantly humid sub-tropical climate with hot, humid summers, severe monsoons and mild winters. Meghalaya is a part of North Eastern Himalayas and it is a landlocked territory with a geographical area of 22 $429 \mathrm{~km}^{2}$, lying between $25^{\circ} 47^{\prime}$ and $26^{\circ} 10^{\prime}$ $\mathrm{N}$ latitude, and $89^{\circ} 45^{\prime}$ and $92^{\circ} 47^{\prime} \mathrm{E}$ longitude, exceptionally rich in biodiversity of insect pests and their natural enemies. Vegetable cultivation is an important part of economy in north eastern states of India including Meghalaya where the geo-climatic condition offers an excellent scope for growing different types of horticultural crops including cole crops which is a major component of diet in this region. Among the many challenges in sustaining crop productivity and nutritional security, direct and indirect damages by insect pests is of paramount importance. Azad et al., (2012) studied the biodiversity of agriculturally important insect in North eastern Himalayan region and documented that, Cole crops, viz., cabbage, cauliflower, radish, Knol-khol and sarson are attacked by a large number of insect pests.

Although some studies have been done, till date no comprehensive information is available on molecular characterization and/or DNA barcoding, especially of insect pests of cole crop ecosystem of India or Meghalaya. Many more unidentified insect species might have been harboring under cole crop ecosystem in this region. Accurate identification of already identified species is also is an issue as evidenced in different species of cabbage white butterfly (Pieris brassicae, $P$. napae, $P$. rapae and $P$. canidia) (Pachuau et al., 2012). Despite of this fact, the comprehensive information on morphological and molecular data on cole crops pest complex is lacking. Therefore, major aim of this study is to develop molecular data by developing DNA barcodes of major insect pest of cole crops ecosystem in mid hills of Meghalaya. The details DNA data base on major insect pests of cole crop ecosystem would be very useful and could be share with other research community and quarantine agencies across the globe.

\section{Materials and Methods}

\section{Location and Site}

Studies on "Development of DNA barcodes for major insect pests of cole crops ecosystem in mid-altitude of Meghalaya" was carried out during 2014-15 in the IPM and Insect Molecular Biology laboratories of Entomology section of Crop Protection 
Division, ICAR Research Complex for North Eastern Hill (NEH) Region, Umiam, Meghalaya. The institute is situated at Umiam (Barapani), 25 $41^{\prime}$ '-21" North latitude and $91^{\circ} 55^{\prime}-25^{\prime}$ 'East longitude having an elevation of $1010 \mathrm{~m}$ above the msl. The climatic condition in this area is of mid tropical zone, with an average annual rainfall of $2810 \mathrm{~mm}$ with maximum temperature range of $20.9^{\circ} \mathrm{C}$ to $27.4^{\circ} \mathrm{C}$ and minimum temperature from $6.7^{0} \mathrm{C}$ to $18.1^{\circ} \mathrm{C}$. The biodiversity of insect pests of cole crops in this area was observed during the experimental period.

\section{Sample collection}

Specimens (Maximum 10 each) were collected from two multiple experimental plots of cole crops at two different locations viz., Entomology experimental farms of Entomology Section and Horticulture Division of ICAR Research Complex for North East Hill Region, Umiam (Barapani), Meghalaya during October 2014 to March 2015 (Table 1). The collected samples were cleaned and placed $\mathrm{n}>95 \%$ ethanol in individual $1.5 \mathrm{~mL}$ Eppendorf tubes until genomic (gDNA) extraction.

\section{Species identification}

Preliminary identification was done based on established taxonomic key or by matching the characters with identified species in Insect Museum of Entomology section of Crop Protection Division, IVAR research complex for NEH Region, umiam, Meghalaya. For further confirmation of the identified species, specimens were also sent to IARI, New Delhi and NBAIR (National Bureau of Agricultural Insect Resources), Bengaluru.

\section{Isolation of genomic DNA}

Total genomic DNA was extracted from all the specimens used in this study by modified phenol: Chloroform method developed by Behere et al., (2007).

The specimens were removed from the individual ethanol vials and allowed to dry in on sterilized blotting paper for an hour at ambient temperature. DNA was extracted from either a single leg or antennae (in case of large insect) and whole insect (in case of aphids etc). in two separate batches for each species along with a negative control; thereby any chance of cross contamination during Gdna extraction could be detected through the inclusion of blank extraction. The DNA and additional two insect voucher specimens of each identified species have been deposited and preserved at insect museum of Entomology section, ICAR Research Complex for NEH, Region, Umiam, India.

\section{Determination of Wolbachia (Bacterial symbiont) infection}

All specimens of identified species were checked for the presence of Wolbachia infection by using Wolbachia gene specific primers: WOL 16S \& WOL 16R (O'Neill et $a l ., 1992$ ) and WSP 81F\& WSP 96R (Zhou et al., 1998) synthesized by Chromous Biotech Pvt. Ltd. Bengaluru, India were used for detection of Wolbachia infection in test insects in this study. For the determination of Wolbachia, we used PCR composition and profile as described in Murthy et al., (2011).

\section{PCR and sequencing}

A partial 709bp cytochrome oxidase I (COI) gene of mtDNA was PCR amplified by using universal primers; LCO-1490 (forward) and HCO-2198 (Reverse) of (Folmer et al., 1994). The PCR (Polymerase chain reaction) amplifications were carried out in thermal cycler (Eppendorf, India) to test the amplifications of all the samples with two standard DNA barcoding primers. The PCR 
reaction was carried out in a total of $10 \mu 1$ volume. PCR profile consist of an initial denaturation at $94^{\circ} \mathrm{C}$ for $2 \mathrm{~min}$, followed by 5 cycles of denaturation at $94^{\circ} \mathrm{C}$ for 30 seconds, annealing at $45^{\circ} \mathrm{C}$ for 40 seconds and extension for $1 \mathrm{~min}$ at $72^{\circ} \mathrm{C}$, again followed by 35 cycles of denaturation at $94^{\circ} \mathrm{C}$ for 30seconds, annealing at $51^{\circ} \mathrm{C}$ for 40 seconds and extension for $1 \mathrm{~min}$ at $72^{\circ} \mathrm{C}$. A final extension was allowed for $10 \mathrm{~min}$ at $72^{\circ} \mathrm{C}$. After the completion of the PCR reactions the amplified products were allowed to hold at $10^{\circ} \mathrm{C}$ for $1 \mathrm{hrs}$ and then stored in $-20^{\circ} \mathrm{C}$. The PCR products were electrophoresed in agarose gel electrophoresis stained with $2 \mu 1$ ethidium bromide and visualized on a UV trans-illuminator. For sequencing, separate PCR reactions were carried out in a total volume of $50 \mu \mathrm{l}$ with LepF1/LepR1 primer and for some samples which were failed to amplify with LepF1 and LepR1 were amplified with LCO and HCO primers.

The PCR profile was similar as described above. After completion of PCR amplification only $10 \mu 1$ of each PCR product was used for gel electrophoresis and documentation. A remaining $40 \mu \mathrm{l}$ Post-PCR product of each species was transferred into $1.5 \mathrm{ml}$ sterilized Eppendorf tubes and the tubes were packed properly and sent for sequencing in frozen conditions to $\mathrm{M} / \mathrm{S}$ Xcelris Pvt. Ltd, Ahmedabad. The nucleotide composition especially AT\% and GC\% for all the species was determined in Clustal W. The AT and GC\% was also determined for first, second and third positions of codon in partial COI gene. For each species a total 2 to 4 samples were sequenced. Each species was bidirectionally sequenced from both the ends (5' and 3').

\section{Sequence analyses}

All the sequenced were analyzed in sequence analysis software Staden Package (Staden et al., 2000). The sequencing analysis was carried of multiple samples of individual species. During sequencing analyses all the sequences were also checked manually within the software for accuracy. The messy 5 ' and 3 ' ends of sequences were trimmed for all the sequences. All sequences were also checked for Open Frame Reading (OFR), and protein translation was carried out by using invertebrates genetic code. Multiple amino acid sequence alignment of all identified species was performed in Clustal X.

\section{Phylogenetic analysis}

The evolutionary relationships/Phylogenetic analysis between different identified species of pest in cole crop ecosystem was also carried out. The evolutionary history was inferred using Maximum Parsimony (MP) method by employing 1000 bootstraps replicates. Out of three trees generated the most parsimonous consensus tree was selected. The Maximum Parsimony tree was obtained using the Subtree-PrunningRegrafting (SPR) algorithm with search level 1 in which the final tress were obtained by the random addition of sequences (10 replicates). The tree was generated based on amino acid sequences of a total of 12 species. Evolutionary analyses were conducted in MEGA6.

\section{Results and Discussion}

\section{Biodiversity of insect pests in cole crops ecosystem of Meghalaya}

The North-Eastern Himalayan region of India is exceptionally rich in terms of flora and fauna and is also considered to be one of the mega biodiversity hotspot in the World (Mayer et al., 2000). In present investigation, a total of 12 insect Pest species were collected, identified and documented from cole crops ecosystem during the year 2014- 
2015 in mid altitude of Meghalaya (Table 2). Out of the 12 species collected, the large white cabbage butterfly ( $P$. brassicae) (Table 2; Plate 1) green peach aphid (Myzus persicae) (Table 2: Plate 4) and tobacco caterpillar (Spodoptera litura) (Table 2; Plate 2) were found to be the most serious pest of cole crops during 2014-15. Diamondback moth (Plutella xylostella) (Table 2; Plate 3) was also found to be the one of the major pest of late planted cole crops. Striped flea beetle (Phyllotreta striolata) (Table 2; Plate 5) leaf beetle (Monolepta quadriguttata) (Table 2; Plate 7), Cabbage looper (Thysanoplusia orichalcea) (Table 2; Plate 12), Cabbage stink bug (Eurydema dominolus) Table 2; Plate 8), small white cabbage butterfly ( $P$. canidia) (Table 2; Plate 10), fruit fly (Bactrocera tau) (Table 2; Plate 11), dipteran fly (Allactoneura sp) (Table 2; Plate 6) and Cabbage heart caterpillar (Crocidolomia pavonana) (Table 2; Plate 9) appeared to be a minor pest. It is well known fact that, the species complex within the same crop ecosystem varied from region to region due to climatic conditions and other factors. A total of 51 insect pests species infesting the cole crops across the World have been reported and documented (Maison, 1965) (Fig. 1).

Another study carried out by Pajmon in 1999 observed about 38 insect pest species in cole crop ecosystem. In India, a total of 37 insect species infesting cole crops across different parts of the country have also been reported (Lal, 1975). The study which was specifically conducted in North-eastern Himalaya reported and documented similar insect pest species on cole crops (Azad et al., 2012). (Firake et al., (2012) also reported and documented 15 insect pests in the cruciferous ecosystem of Meghalaya where the large white cabbage butterfly ( $P$. brassicae) and mustard aphid ( $L$. erysimi) was the most serious pest of vegetable brassica (cole crops). In present investigation, $P$. xylostella was observed to be the late season pest of cole crops in the cole crop ecosystem of Meghalaya. The striped flea beetle, $(P$. striolata) (Table 2; Plate 5) was reported for the first time as insect pests on cole crops from north east India. Similarly and as per the existing literature scan, the Bactrocera tau (Table 2; Plate 11) has also not been reported as a pest of cole crops from India. B. tau was found to be the minor pests of knol-khol in mid altitudes of Meghalaya.

The preliminary identification of the collected insect pests were established based on known taxonomic keys. The species/specimens which were difficult to identify based on known taxonomic keys were sent to ICARNBAIR, Bengaluru or IARI, New Delhi, India. Based on their taxonomic classification, the collected 12 specimens were classified under five major insect orders, Diptera (2), Lepidoptera (6), Coleoptera (2) and Hemiptera (2). The images of the insect whenever possible were also documented and all these information are presented in Table 2.

\section{Detection of Wolbachia (Bacterial symbiont) infection on cole crops pests}

Wolbachia are also transmitted horizontally between arthropod species (Avtzis et al., 2014). As the determination of presence of Wolbachia infection is a pre requisite for any insect DNA barcoding research work. All species of insects analyzed in this study were found to be free from endosymbiont Wolbachia infection except for E. dominolus, belonging to family Pentatomidae (Hemiptera) in which all the specimens were tested with two different pairs of primers specific to Wolbachia genes. Werren and Windsor, (2000) reported that 15 to $75 \%$ of insect species harbor Wolbachia, it was detected in each of the major insect orders, including Coleoptera, Diptera, Hemiptera, Homoptera, Hymenoptera, Lepidoptera, and 
Orthoptera. In present investigation Wolbachia was detected in the insect order Hemiptera which had stink bug E. dominulus (Table 2; Plate 8). The finding reported on Wolbachia in this study was further supported by Whitworth et al., (2007), who observed that the patterns of mitochondrial variability was related to the spread of maternally transmitted bacteria that co-segregate with mitochondria. During the DNA barcoding of different species of bird blowfly Protocalliphora, a total of 12 species of Protocalliphora were found positive for Wolbachia infection (Whitworth et al., 2007) hence the barcoding was not possible for almost $60 \%$ species of Protocalliphora. Due to the Wolbachia infection DNA barcoding work not possible as this technique might underestimate the observed genetic variations in target species. Smith et al., (2005) analyzed more than 2 million insect COI trace files on the BOLD and reported that Wolbachia COI was present in $0.16 \%$ of the cases and concluded that the presence of the Wolbachia. DNA in total genomic extracts made from insects was unlikely to compromise the accuracy of the DNA barcode library and suggested that regular assays for Wolbachia presence should be undertaken for any DNA barcoding project. Considering and keeping in mind the above mentioned points, the samples which were positive for presence of Wolbachia infection were discarded and were not used for further DNA barcoding work as infection could manipulate the COI DNA barcoding results.

\section{Sequencing analysis and Submission of sequence to NCBI}

The target region of COI gene was successfully amplified in all specimens, and the good quality sequences obtained. No INDELs (Insertion and deletions) were detected among the sequences, hence the sequence analysis and alignment was easily carried out. The molecular identity of all the specimens was successfully established through BLASTn search at National Centre for Biotechnology (NCBI), where all the 12 species shows $95-100 \%$ identity with reported sequences in the NCBI GenBank

DNA was successfully extracted from all the 12 species using modified Phenol: Chloroform method. The DNA barcodes based on partial COI gene for all the 12 species have been developed. The total length of DNA barcodes varied from species to species and it was ranged from 572 to $677 \mathrm{bp}$. The shortest good quality sequenced was obtained from $C$. pavonana and the longest good quality final sequenced was obtained from $P$. brassicae and $P$. canidia. For others 10 species the final analyzed sequence length was always more than 600bp.

All the 12 DNA barcodes have been deposited to NCBI and accession numbers were obtained for all of them. All analyzed sequences have been submitted to NCBI vide accession numbers KT175576 - KT175605. The nucleotide composition of all the 12 sequence was AT rich and no significant variations were observed in terms AT and GC\% at first, second and third position of codon. The evolutionary relationships/ Phylogenetic analysis between different identified species of insect pests in cole crops ecosystem was inferred using Maximum Parsimony (MP) method. After 1000 bootstrap replications all the insect species group together as per their insect order.

In this study, we have analysed and documented only 12 insect pests, but there may be more species harboured in this region of India. Therefore, additional studies have to be undertaken to get a clear picture of insect pests diversity and the pest status in the region. 
Table.1 Collection details of specimen during experimental season (2014-15)

\begin{tabular}{|c|c|c|c|c|c|c|c|c|}
\hline \multicolumn{9}{|c|}{ Table 1. Collection details of specimen during experimental season (2014-15) } \\
\hline Sl.no & $\begin{array}{c}\text { Name of insect } \\
\text { species }\end{array}$ & Order & Family & $\begin{array}{c}\text { Date of } \\
\text { collection }\end{array}$ & Host & $\begin{array}{c}\text { Total } \\
\text { bp }\end{array}$ & Location & $\begin{array}{c}\text { NCBI accession } \\
\text { number }\end{array}$ \\
\hline 1 & Pieris brassicae & Lepidoptera & Pieridae & Nov. 2014 & Cabbage & 677 & Ento.Field & KT175597 \\
\hline 2 & Pieris canidia & Lepidoptera & Pieridae & Nov. 2014 & Cabbage & 677 & Ento.Field & KT175605 \\
\hline 3 & Plutella xylostella & Lepidoptera & Plutellidae & Nov. 2014 & Cabbage & 663 & Ento.Field & KT175591 \\
\hline 4 & Spodoptera litura & Lepidoptera & Noctuidae & Nov. 2014 & Cabbage & 638 & Ento Field & KT175579 \\
\hline 5 & $\begin{array}{c}\text { Monolepta } \\
\text { quadriguttata }\end{array}$ & Coleoptera & Chrysomelidae & Nov. 2014 & Knol-khol & 654 & Ento.Field & KT175583 \\
\hline 6 & $\begin{array}{c}\text { Thysanoplusia } \\
\text { orichalcea }\end{array}$ & Lepidoptera & Noctuidae & Nov. 2014 & Cabbage & 646 & Horti Field & KT175604 \\
\hline 7 & Bactrocera tau & Diptera & Tephritidae & Nov. 2014 & Knol-khol & 664 & Horti Field & KT175576 \\
\hline 8 & $\begin{array}{l}\text { Crocidolomia } \\
\text { pavonana }\end{array}$ & Lepidoptera & Crambidae & Nov. 2014 & Cauliflower & 572 & Ento. Field & KT175582 \\
\hline 9 & Phyllotreta striolata & Coleoptera & Chrysomelidae & Feb. 2015 & Radish & 668 & Ento. Field & KT175603 \\
\hline 10 & Eurydema dominulus & Hemiptera & Pentatomidae & Feb. 2015 & Cabbage & 604 & Ento. Field & KT175600 \\
\hline 11 & Allactoneura sp & Diptera & Mycetophilidae & Feb. 2015 & Radish & 639 & Horti Field & KT175590 \\
\hline 12 & Myzus persicae & Hemiptera & Aphididae & Feb. 2015 & Cauliflower & 641 & Ento. Field & KT175584 \\
\hline
\end{tabular}

*bp- base pair 
Table.2 Image and Biodiversity of insect pests of cole crops ecosystems in mid altitude of Meghalaya

\begin{tabular}{|c|l|l|l|c|}
\hline Sl.no & Common name & Scientific name & Pest status & Plate no. \\
\hline 1. & Large white cabbage butterfly & Pieris brassicae & Major pest & 1 \\
\hline 2. & Tobacco caterpillar & Spodoptera litura & Major pest & 2 \\
\hline 3. & Diamondback moth & Plutella xylostella & Major pest & 3 \\
\hline 4. & Green peach aphid & Myzus persicae & Major pest & 4 \\
\hline $\mathbf{5 .}$ & Striped flea beetle & Phyllotreta striolata & Minor pest & 5 \\
\hline $\mathbf{6 .}$ & Dipteran fly & Allactoneura sp & Minor pest & 6 \\
\hline 7. & Leaf beetle & Monolepta quadriguttata & Minor pest & 7 \\
\hline 8. & Cabbage stink bug & Eurydema dominulus & Minor pest & 8 \\
\hline 9. & Cabbage heart caterpillar & Crocidolomia pavonana & Minor pest & 9 \\
\hline $\mathbf{1 0 .}$ & Small white cabbage butterfly & Pieris canidia & Minor pest & 10 \\
\hline $\mathbf{1 1 .}$ & Fruit fly & Bactrocera tau & Minor pest & 11 \\
\hline $\mathbf{1 2}$ & Cabbage semilooper & Thysanoplusia & Minor pest & 12 \\
\hline & & orichalcea & & \\
\hline
\end{tabular}


Fig.1

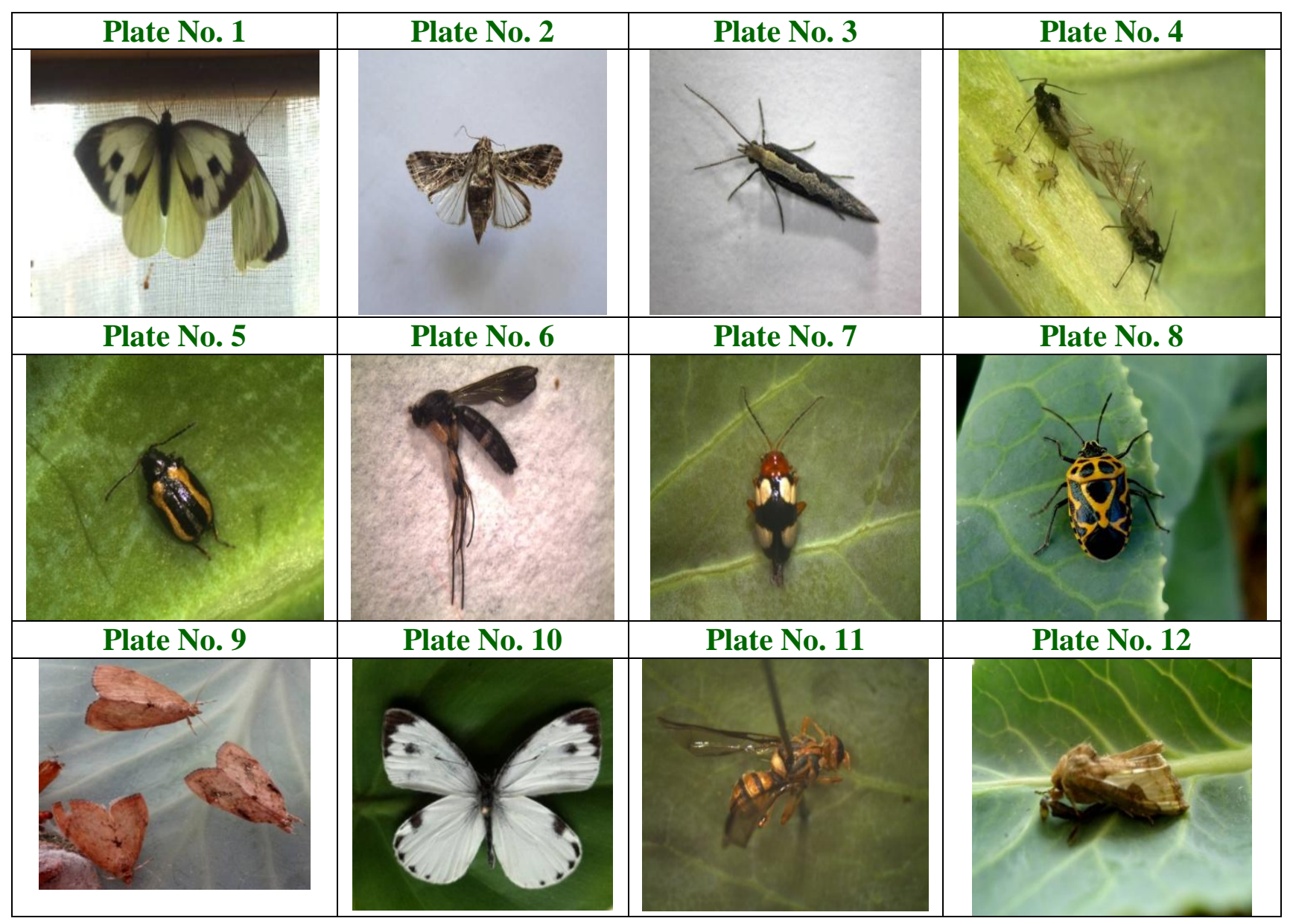


The comprehensive data generated from present study would be useful in further understanding of the biodiversity of arthropod fauna associated with cole crops in other regions of the country and this study would certainly have implications for pest management, taxonomy, quarantine and trade and for development of diagnostic guide at both morphological and molecular level.

\section{Acknowledgement}

The authors are thankful to Division of crop protection, Entomology, ICAR, Research Complex for NEH Region and School of Crop Protection, College of Post Graduate Studies, Umiam Barapani for providing the field and necessary lab facilities for conducting this research.

\section{References}

Avtzis, D.N., Doudoumis, V. and Boutzis, K. (2014). Wolbachia infection and mitochondrial diversity of two chestnut feeding, Cydia species. doi: s10.1371/s0112795

Azad, N.S., Firake, D.M., Behere, G.T., Firake, P.D. and Saikia. K. (2012). Biodiversity of Agriculturally Important Insects in North Eastern Himalaya: An Overview. Indian J. Hill Fmg, 25(2): 37-40.

Behere, G.T., Tay, W.T., Russell, D.A., Heckel, D.G., Appleton, B.R., Kranthi, K.R. and Batterham, P. (2007). Mitochondrial DNA analysis of field populations of Helicoverpa armigera (Lepidoptera: Noctuidae) and of its relationship to $H$. zea. BMC Evol. Biol., 7: 117.

Dhaliwal, G.S., Dhawan, A.K. and Singh, R. (2007). Biodiversity and ecological agriculture: Issues and perspectives. Indian J. Ecol., 34(2): 100-109.

Firake, D.M., Lytan, D. and Behere, G.T.
(2012). Bio-diversity and seasonal activity of arthropod fauna in Brassicaceous crop ecosystems of Meghalaya, North East. India Mol. Entomol., 3(4): 18-22.

Folmer, O., Black, M., Hoeh, W., Lutz, R. and Vrijenhoek, R. (1994). DNA primers for amplification of mitochondrial cytochrome c oxidase subunit I from diverse metazoan invertebrates. Mol. Marine Biol. Biotech., 3: 294-299.

Heywood, V.H. (1993). Flowering plants of the world. Oxford University Press, New York, pp. 355.

Lal, O. P. (1975). A Compendium of insect pest of vegetables in India. Bull. Entomol., 16: 31-56.

Maison, B.L. (1965). Insect pest of crucifers and their control. Annual Rev. Entomol., 10: 233-256.

Mayer, N., Muttermeier, R.A., Muttermeier, C.A. and Kent J. (2000). Biodiversity hotspots for conservation priorities. Nature, 403: 853-858.

Murthy KS, Rajeshwari. R, Venkatesan T, Baby NL. 2011. Detection and characterization of Wolbachia in Cotesia plutellae (Kurdjumov) (Hymenoptera: Braconidae), a parasitoid of the diamond back moth Plutella xylostella (Linn.). J. Biol Control 25: 213-216

O’Neill, S. L., Giordano, R., Colbert, A. M. E., Karr, T. L. and Robertson, H. M. (1992). 16S rRNA phylogenetic analysis of the bacterial endosymbionts associated with cytoplasmic incompatibility in insects. Proc. Natl. Acad. Sci.USA., 89: 26992702.

Pachuau, L., Vanlalruati, C. and Kumar, N.S. (2012). Morphological versus molecular characterization of three similar Pierid species of butterflies. Int. J. Pharm. Biol. Sci., 3: 1091-1102. 
Pajmon, A. (1999). Pest of cabbage. Sodobna kemetijstvo, 32: 537-540.

Reddy, K.V.S. and Zehr, U.B. (2004). Novel strategies for overcoming pests and diseases in India. $4^{\text {th }}$ International Crop Science Congress http://www.cropscience.org.au/icsc20 04 /symposia/3/7/153_zehrub.htm. Accessed 23 April 2015.

Smith, M.A, Woodley, N.E, Janzen, D.H, Hallwachs W. and Hebert, P.D.N. (2005). DNA barcodes reveal cryptic host-specificity within the presumed polyphagous members of a genus of parasitoid flies (Diptera: Tachinidae). Proc. Natl. Acad. Sci. U.S.A., 103(10): 3657-3662.

Staden, R., Beal, K. F, Bonfield, J. K. (2000). The Staden package. Methods in
Molecular Biology, 132:115-300.

Werren, J.H. and Windsor, D M. (2000). Wolbachia infection frequencies in insects: evidence of a global equilibrium? Proc. R. Soc. B., 267: 1277-1285

Whitworth, T.L., Dawson. R.D., Magalon, H. and Baudry, E. (2007). DNA barcoding cannot reliably identify species of the blowfly genus Protocalliphora (Diptera: Calliphoridae). Proc. R. Soc. B., 274(1619): 1731-1739.

Zhou, W., Rousset, F. and O'Neill, S. L. (1998). Phylogeny and PCR - based classification of Wolbachia strains using wsp gene sequences. Proc. $R$. Soc. Lond. Ser. B., 265: 509-515.

\section{How to cite this article:}

Larinfeli, R., G.T. Behere, D.M. Firake, Bhagawati Sharma, Amrita Banerjee and Rajesh, T. 2019. Development of DNA Barcodes for Major Insect Pest of Cole Crops in Mid-Hills of Meghalaya. Int.J.Curr.Microbiol.App.Sci. 8(02): 789-799.

doi: https://doi.org/10.20546/ijcmas.2019.802.091 